\title{
FTTH OPTIKAI HÁLÓZAT TERVEZÉSE
}

\author{
Varga Attila Károly \\ egyetemi docens, Miskolci Egyetem, Automatizálási és Infokommunikációs Intézet \\ 3515 Miskolc, Miskolc-Egyetemváros, e-mail:vvarga.attila@uni-miskolc.hu
}

\author{
Hegedüs Péter \\ okl. villamosmérnök \\ e-mail: hegedus.peter.jozsef@gmail.com
}

\begin{abstract}
Absztrakt
Mára már valamennyi multimédiás szolgáltatás internethasználattal érintett, különbözö streamer szolgáltatások jelentek meg, ezáltal egyre nagyobb sávszélességre mutatkozik igény. Többek között ezen igények kiszolgálására hivatott az egyre szélesebb körben elterjedt felhasználói végpontig kiépitett fényvezetös hálózat (FTTH: Fiber-to-the-Home). Az FTTH drámai módon megnöveli a számitógép-felhasználók számára elérhetö kapcsolati sebességet a többi hálózati technológiához képest. Jelen cikk keretében az FTTH hálózat tervezésének lépéseit [1], az irányadó elöirások alapján figyelembe veendö szempontokat kivánjuk bemutatni. A cikkel szeretnénk arra is rámutatni, hogy az összes épitéssel érintett tervezésnél fontos a csapatmunka, az összehangolt koordináció, ugyanis a munka gördülékeny elörehaladását, az egymásra épülö munkafázisok sikeres lezárását jelentösen befolyásolja az érintett cégekkel való egyeztetés, mérnökökkel, szakemberekkel való konzultálás.
\end{abstract}

Kulcsszavak: optikai hálózat, FTTH, hálózattervezés, közös oszlopsor, saját oszlopsor, földalatti alépítmény, kiviteli terv

\begin{abstract}
Today, all multimedia services are affected by the use of the Internet, various streamer services are emerging, thus increasing the demand for bandwidth. Among other things, the fiber-to-the-home (FTTH) network is designed to serve these needs. FTTH dramatically increases the communication speed available to computer users compared to other network technologies. The goal of this publication is to present the steps of planning an FTTH network, the aspects to be taken into account according on the basis of the applicable regulations. With this publication we would like to point out that teamwork and coordinated coordination are important in all planning related to construction, as the progress and the successful completion of the work phases, which are based on each other, are significantly influenced by consultation with engineers and specialists.
\end{abstract}

Keywords: optical network, FTTH, network design, joint-use poles, private poles, underground substructure, construction plan

\section{Bevezetés}

Ugyan az internet már lehetővé teszi, hogy komolyabb titkosításokkal akár kontinensek között is megoldható legyen a gyárak folyamatos kommunikációja, de a gyárak belső hálózata még sok esetben nem optikai kábelezéssel lett kialakítva. Az FTTH hálózat müködtetéséhez OLT (Optical Line Termination) szükséges, ami egy optikai rendező, ahova minden szálat ki kell fejteni, majd innen csak azok a szálak 
kerülnek drop kábel segítségével bekötésre (a szerverbe), amelyek a hálózat üzemeltetéséhez szükségesek. Fontos kiemelni, hogy passzív osztókat használ (0. szint, 1. szint, 2. szint, ld. 2. ábra), mely rendkívül költséghatékony megoldás. [2] [3]

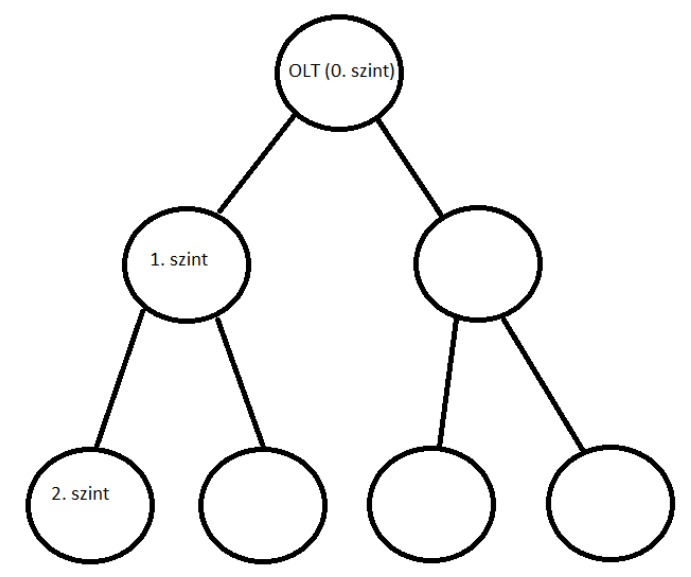

1. ábra. Passziv osztók müködése

A nulladik szintủ osztó az optikai rendező és az OLT között található. Hasznos, mert megduplázza az OLT bemenetei számát, ugyanakkor lassul a hálózat sebessége (1:2 osztással szokták alkalmazni). A lefedő hálózatban 1-es és 2-es szintủ osztókat használunk. Az OLT-ből az egyes szintü osztóba, onnan pedig a kettes szintü osztóba megy a fény. A kettes szintủ osztókból már a végberendezésbe visszük a kommunikációs csatornát. A kettes szintủ osztó az utolsó hálózatba tervezendő elem. A kettes szintủ osztótól az ONU-ig drop kábeleket használunk. Az ONU gyakorlatilag egy modem, ami a technológia végződtetése, de ennek bekötése már az üzemeltető feladata, ha a szolgáltatásra megrendelés érkezik.

\section{Az FTTH hálózat tervezése során mérlegelendő szempontok}

Tegyük fel, hogy érkezik egy megrendelés egy hálózat kialakítására, hivatalosan megvásárolt földhivatali alaptérképpel és irányelvekkel. Ez lehet egy felhordó hálózat vagy egy lefedő hálózat. Ebben az esetben a megrendelő által biztosítandó alapvető információk:

- tervezendő terület mérete,

- építési módok,

- technológia,

- dokumentálás mennyisége.

A fenti információk megadását követően megtörténik a terület felmérése. Itt fontos megjegyeznem, hogy bár a Google Mapsben vannak olyan települések, illetve területek, amelyek feltérképezhetőek számítógép előtt ülve is, de ez nem pótolja a helyszíni bejárást. Erre tekintettel a helyszíni bejárás elengedhetetlen. Az FTTH hálózat megépítése kapcsán háromféle lehetőség adódik:

- valamilyen közös oszlopsor felhasználása (E.ON oszlopsor, Telekom oszlopsor, saját meglévö oszlopsor/meglévő alépítmény),

- saját oszlopsor tervezése,

- saját alépítmény tervezése.

A nyomvonalnak, egyenes vonalú és alépítmény elvi rajznak nincs szabványos formai megkötése, jelenleg kidolgozás alatt áll az egységes szakági rajzkészlet. Ugyanakkor ettől függetlenül kialakult egy 
általános forma, amit a MATÁV, későbbi Telekom használ. Jelenleg úgy tűnik, hogy ennek egy továbbfejlesztett verziója lesz a szabványos rajzkészlet.

A szálkiosztási rajz ábrázolja a rendszer müködését, amely megmutatja, hogy az információ hogyan közlekedik az optikai szálakban. A szálkiosztási rajz elkészítéséhez komoly szaktudás szükséges. Ez a rajzfajta szemlélteti, hogy hogyan jutunk el OLT-töl az ONU-ig.
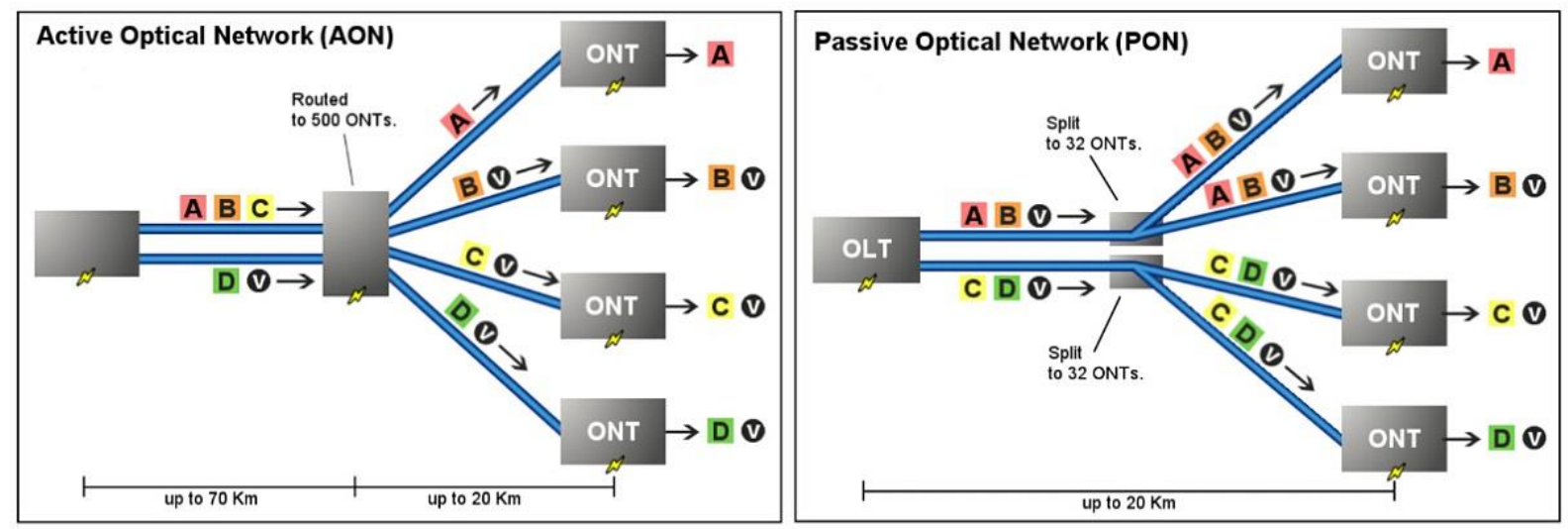

Key: A - Data or voice for a single customer. $\quad$ D - Video for multiple customers.

2. ábra. Aktív/Passzív optikai hálózat [2] [3] [4]

\section{3. Áramszolgáltató oszlopsorának igényvétele}

Közös oszlopsoros kivitelezésnél figyelembe kell venni a meglévő hálózat állapotát, struktúráját, mivel szinte minden esetben valamilyen beavatkozás szükséges. Ez a fajta tervezés az NMHH eljárásban egy egyszerüsített eljárás, mivel előzetes bejelentéssel beszerezhető rá az építési engedély.

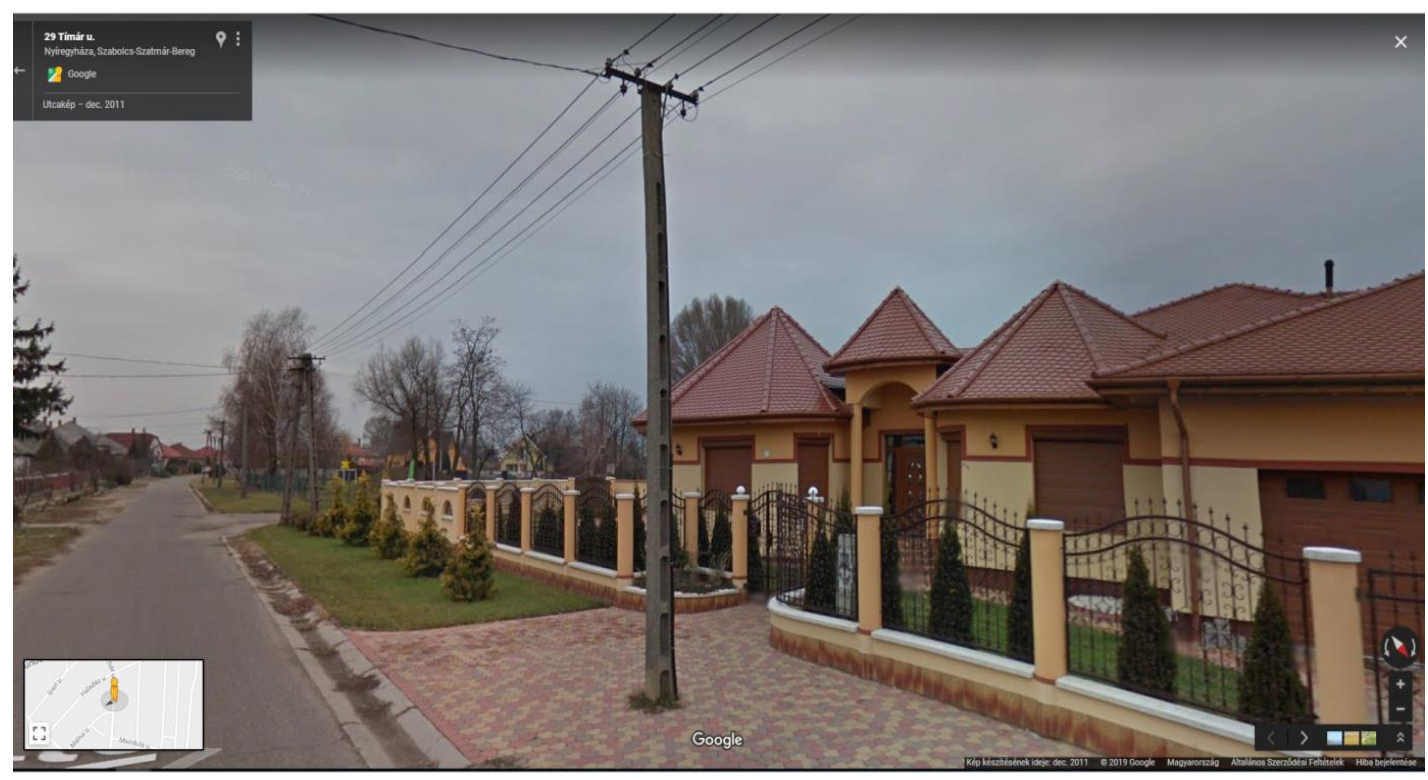

2. ábra. Áramszolgáltató oszlopsora 
Fontos kiemelni, hogy elhelyezési és szabványosítási terveket csak erősáramú jogosultsággal rendelkező szaktervező készíthet. Az, hogy valaki rendelkezik erősáramú tervezői jogosultsággal, nem azt jelenti, hogy automatikusan tervezhet szabványosítási tervet, ugyanis meg kell nézni, hogy az áramszolgáltató milyen feltételeket ír elö. Például, az E.ON esetében csak olyan cég készíthet tervet, amely az áramszolgáltatónál is le van minősítve, mint tervező. Ettől függetlenül, előzetesen a távközlési tervezönek is tisztában kell lennie az oszlopok minőségével és a kábel elhelyezésének optimális megoldási lehetőségeivel.

Mindamellett, hogy a kábelek elhelyezhetőséget és a szabványosságot a szakemberek ránézésre is meg tudják állapítani, valamennyi elhelyezési szabály és szabvány betartása kötelező érvényü.

Meglévő hálózat felhasználása esetében a tulajdonos feltételeit maximálisan figyelembe kell venni. Ilyen esetben elengedő egy müszaki ellenőr jegyzőkönyve és adatszolgáltatása, hogy mely meglévő oszlopnál milyen beavatkozásra van szükség.

\section{Saját oszlopsoros tervezés}

Saját oszlopsoros tervezés esetén első körben meg kell vizsgálni, hogy elhelyezhetö-e az oszlopsor, illetve hogyan illeszkedik a település rendezési tervéhez. Továbbá, tervezés előtt szükséges egy összközmüves térkép beszerzése is. Figyelembe kell venni a település arculatát, sajátosságait.

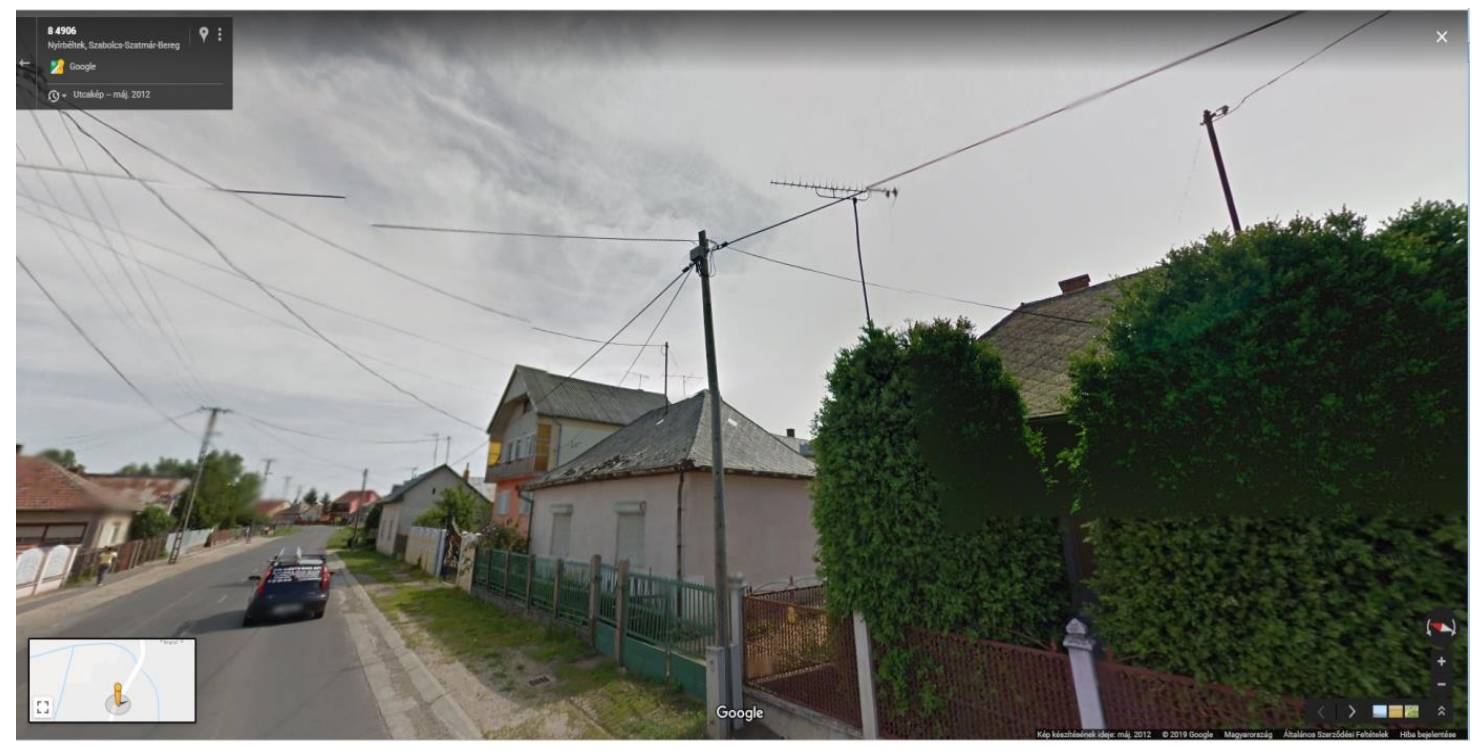

\section{3. ábra. Távközlö oszlopsor}

A Nemzeti Média és Hírközlési Hatóság akár 2, 3 vagy 4 oszlopsor építését is engedélyezi, de itt az utak tulajdonosának is bele kell egyeznie az építésbe, valamint egyeztetni kell az önkormányzattal és/vagy a Magyar Közúttal. Egy utcában maximum 2 oszlopsor megoldás elegáns, az úttest két oldalán, mivel ez a megoldás kevésbé zavarja a település összképét és az ott élő lakosság komfortérzetét.

Ebben az esetben is fontos figyelembe venni a föld alatt futó közmüveket. Szükséges beszerezni az összközműves alapadatokat, melyek az e-közmủ rendszerben elérhetőek (pár ezer forintért) azok számára, akik rendelkeznek tervezői jogosultsággal. 


\section{Saját földalatti alépítmény}

Saját földalatti alépítményes megoldásnál az összközmüves térképhasználat a kiindulási pont, csak ezután lehet elkezdeni a felmérést. Itt is, mint a saját oszlopsorépítésnél is, figyelembe kell venni a közmüvek helyét, a burkolatokat, a kapubehajtókat stb. Ez a megoldás a legdrágább beruházás, de hosszútávon a legköltséghatékonyabb az ilyen építési módot választó szolgáltatóknak, ugyanis hosszabb távon olcsóbb az üzemeltetése.

Következö lépés, hogy egyeztetünk a megrendelővel és felkérjük a geodétákat a terület bemérésére. Ily módon hozzájutunk a kapuk, behajtók, utak EOV koordinátás alapadatához, mely révén elindulhat a nyomvonaltervezés. Figyelembe kell venni, hogy a potenciális előfizetőkhöz eljuttatható legyen az internetbekötés későbbi lehetősége (biztosítható, ha mủanyag csővel az ingatlanhatárig/kerítés vonaláig kerül kiépítésre a hálózat).

A tervezett nyomvonalat méretezni is kell, a víz- és gázvezeték „V”, illetve „G” betű jelöli a rajz. Nagyon fontos, hogy a színezést a kivitelezőkkel mindenképpen egyeztetni kell.

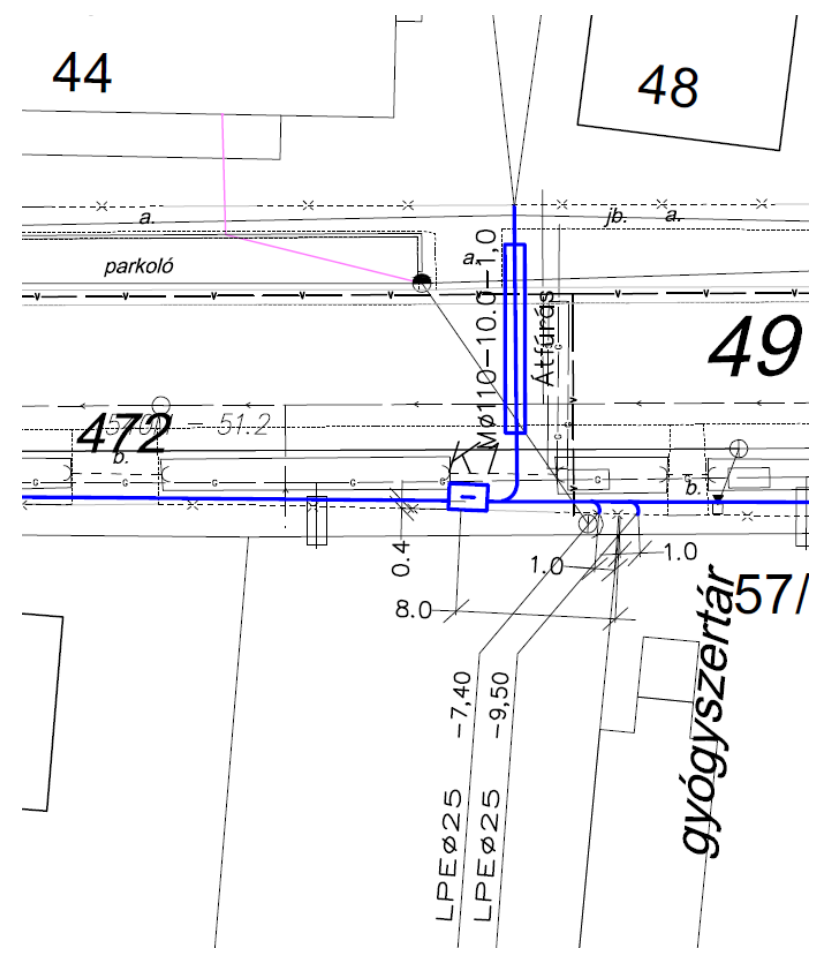

4. ábra. Részlet alépítményes nyomvonalrajzból

\section{Kiviteli terv benyújtása}

A Nemzeti Média és Hírközlési Hatósághoz háromféleképpen lehet kiviteli terveket benyújtani:

- elözetes bejelentéssel,

- utólagos bejelentéssel,

- építési engedélyre. 


\subsection{Kiviteli terv benyújtása előzetes bejelentéssel}

Előzetes bejelentésnél (jelenleg már csak elektronikus benyújtásra van lehetőség) a benyújtáshoz szükséges 1 darab kiviteli tervdokumentáció, melynek tartalma:

- átnézeti rajz,

- nyomvonalrajz,

- müszaki leírás,

- helyrajzi számos lista,

- költségvetés,

- egyeztetetett szervek jegyzéke,

- tervjóváhagyó jegyzőkönyv,

- meghatalmazás (ha nem a beruházó adja be a hatóságnak),

- NMHH kitöltött adatlapja,

- utalási bizonylat és/vagy illetékbélyegek, amelyek az adatlapon kerülnek elhelyezésre.

\subsection{Kiviteli terv benyújtása utólagos bejelentéssel}

Utólagos bejelentés (szintén már csak elektronikus benyújtásra van lehetőség), ezt a fajta eljárást akkor kell választani, ha a tervezett nyomvonal hossza 100 méter alatt van, illetve abban az esetben, ha az előzetes bejelentéses eljárás kivitelezésre került, és lezárták az építési naplót. A benyújtáshoz szükséges 1 darab kiviteli tervdokumentáció, melynek tartalma:

- átnézeti rajz,

- nyomvonalrajz,

- müszaki leírás,

- helyrajzi számos lista,

- költségvetés,

- egyeztetetett szervek jegyzéke,

- tervjóváhagyó jegyzőkönyv,

- meghatalmazás (ha nem a beruházó adja be a hatóságnak),

- NMHH kitöltött adatlapja,

- utalási bizonylat.

\subsection{Kiviteli terv benyújtása építési engedélyre}

Építési engedély, a benyújtáshoz szükséges 3 darab kiviteli tervdokumentáció, melynek tartalma (megvalósítás alatt az elektronikus benyújtás):

- átnézeti rajz,

- nyomvonalrajz,

- elvi rajz,

- szálkiosztási rajz/kötéslapok,

- müszaki leírás,

- helyrajzi számos lista,

- költségvetés,

- egyeztetetett szervek jegyzéke,

- építési nyilvántartó lap,

- bontási nyilvántartó lap, 
- tervjóváhagyó jegyzőkönyv,

- meghatalmazás (ha nem a beruházó adja be a hatóságnak),

- NMHH kitöltött adatlapja.

Továbbá, építési engedélyre való benyújtásnál szükség van szakhatóságok hozzájárulására is, melyet be lehet szerezni előzetesen vagy a Nemzeti Média és Hírközlési Hatóságon keresztül. A szakhatósági engedélyezési terv tartalma:

- átnézeti rajz,

- nyomvonalrajz,

- müszaki leírás,

- helyrajzi számos lista,

- költségvetés,

- (gázszolgáltató jegyzőkönyve a bányakapitányságnak).

A szakhatóságok, amelyeknek hozzá kell járulnia az építési engedélyhez:

- a település jegyzője,

- honvédség,

- tüzvédelmi hatóság,

- kulturális és örökségvédelmi hatóság,

- környezet- és természetvédelmi hatóság,

- Magyar Bányászati és Földtani Szolgálat (ha külterületet érint).

\section{7. Összefoglalás}

Jelen publikációban bemutattuk az FTTH optikai internethálózat tervezésének legfontosabb lépéseit, mely kapcsán fontos szempont, hogy költséghatékony, ugyanakkor müszakilag könnyen kivitelezhető legyen.

A hírközlési tervekre vonatkozó szabványokat a MSZ 7487 és MSZ 13207 írja le, amelyeket a tervezés során figyelembe kell venni, továbbá meg kell felelni az elektronikus hírközlési építmények elhelyezéséről és az elektronikus hírközlési építményekkel kapcsolatos hatósági eljárásokról szóló NMHH 14/2013-as rendelet elöírásainak is. Minden közműnek, hírközmünek van egy védőövezete, amit figyelembe kell venni a tervezés, kivitelezés során, és emellett a Magyar Közút Nonprofit Zrt. előírásait is be kell tartani. Az elöírások a legtöbb esetben minden további nélkül betarthatók, ugyanakkor mivel korábban nem volt egységes szabályrendszer (inkább ajánlás jelleggel léteztek, nem voltak kötelezö jellegüek), a jelenlegi kivitelezések során a védöövezetek betartása sok esetben megoldandó akadályoztatást jelent, ilyenkor az egyeztetések folyamán felveszik a kapcsolatot a tervezővel az adott közmủ illetékesei. Az engedélyek beszerzése, és az egyeztetések során előfordulhat, hogy bizonyos részeket újra kell tervezni, ezért az egyeztetéseket kellő hangsúllyal kell kezelni, nem szabad az utolsó pillanatra hagyni, amikor már elörehaladottabb fázisban tart a tervezés. [5] [6] [7] [8]

\section{Köszönetnyilvánítás}

A cikkben ismertetett kutatómunka az EFOP-3.6.1-16-2016-00011 jelü Fiatalodó és Megújuló Egyetem - Innovatív Tudásváros - a Miskolci Egyetem intelligens szakosodást szolgáló intézményi fejlesztése projekt részeként - a Széchenyi 2020 keretében - az Európai Unió támogatásával, az Európai Szociális Alap társfinanszírozásával valósul meg. 


\section{Irodalom}

[1] Magyar Mérnöki Kamara: FTTH tervezési irányelvek. https://hit.mmk.hu/dokumentumok/fap $2015 \mathrm{fttxbin}$

[2] Prat, J. (2010). Next-generation FTTH Passive Optical Networks. Springer, ISBN 978904 8178896

[3] Zheng, Y., Mao, Z., Di, L., Ge, Z., Zhang, X., Sun, X. (2017). Low latency passive optical node for optical access network. 16th International Conference on Optical Communications and Networks (ICOCN), Wuzhen, 2017, pp. 1-2, https://doi.org/10.1109/ICOCN.2017.8121485

[4] http://sfp.hatenablog.com/entry/2015/06/19/164953

[5] Magyar Szabványügyi Testület, mszt.hu

[6] Az elektronikus hírközlési épitmények elhelyezéséröl és az elektronikus hírközlési épitményekkel kapcsolatos hatósági eljárásokról szóló NMHH 14/2013-as rendelet,

https://net.jogtar.hu/jogszabaly?docid=a1300014.nmh

[7] https://internet.kozut.hu/

[8] https://www.e-epites.hu/e-kozmu 